This item was submitted to Loughborough's Research Repository by the author.

Items in Figshare are protected by copyright, with all rights reserved, unless otherwise indicated.

\title{
Canonical in the 1930s: Willa Cather's death comes for the archbishop in the modern library series
}

\section{PLEASE CITE THE PUBLISHED VERSION}

http://dx.doi.org/10.1353/sdn.2013.0022

\section{PUBLISHER}

(c) 2013 The Johns Hopkins University Press

\section{VERSION}

AM (Accepted Manuscript)

\section{PUBLISHER STATEMENT}

This work is made available according to the conditions of the Creative Commons Attribution-NonCommercialNoDerivatives 4.0 International (CC BY-NC-ND 4.0) licence. Full details of this licence are available at: https://creativecommons.org/licenses/by-nc-nd/4.0/

\section{LICENCE}

CC BY-NC-ND 4.0

\section{REPOSITORY RECORD}

Jaillant, Lise. 2019. "Canonical in the 1930s: Willa Cather's Death Comes for the Archbishop in the Modern Library Series”. figshare. https://hdl.handle.net/2134/20558. 


\section{CANONICAL IN THE 1930s: WILLA CATHER'S \\ DEATH COMES FOR THE ARCHBISHOP IN THE MODERN LIBRARY SERIES}

In 1931, the Modern Library series reprinted Willa Cather's Death Comes for the Archbishop and sold it for only ninety-five cents. ${ }^{1}$ For Bennett Cerf and Donald Klopfer, the young owners of the Modern Library, this was a victory after years of unsuccessful attempts to include Cather titles in their series. However, Archbishop stayed only five years in the Modern Library. At Cather's insistence, Alfred Knopf, the original publisher, refused to renew the contract, and Cerf and Klopfer had to drop the novel from their list. While Sharon O'Brien has argued that "Willa Cather possessed canonical status during the 1920s only to lose it in the 1930s" (111), my essay contends that some of Cather's works became canonical in the early 1930s-when these texts were included in cheap series of reprints such as the Modern Library and Houghton Mifflin's Riverside Library, and marketed to a large audience of students and their professors. As John Guillory puts it, "canonicity is a function of the reproduction of a work over time, and the market for such reproduction is the school" (53 n5). The canonicity of Archbishop and other Cather titles was indeed the product of the education system (the principal canon maker for Guillory) but also of reprint series, which made these titles easily available to the school market. At the time when the study of American literature was being institutionalized in universities, many instructors selected the inexpensive editions of Cather titles for classroom use. Cather's opposition to such dissemination of her fiction had long-term consequences: as she was increasingly attacked by a new generation of Marxist critics, Cather made little attempt to reach the academics that continued to admire her work. She was competing with other American writers whose novels were easily available in the Modern Library and other cheap series, and yet, she underestimated the importance of these series in canon making. ${ }^{2}$ 
The Modern Library series can be seen as a middlebrow enterprise that, in Trysh Travis's words, "offered to mediate literary culture for modern audiences in need of guidance" (340). ${ }^{3}$ When Albert Boni and Horace Liveright launched the series in New York in 1917, they targeted the growing number of readers interested in contemporary literature. The first list of the Modern Library included H. G. Wells's Ann Veronica and War in the Air, Oscar Wilde's Dorian Gray, Guy de Maupassant's Mademoiselle Fifi, and plays by Ibsen, Shaw, and Strindberg. Unlike Everyman's Library and other cheap publisher's series that specialized in out-of-copyright works, the Modern Library reprinted not only older classics but also recent, copyrighted texts. Consumers were encouraged to buy the Modern Library to increase their confidence and social status. One of the first advertisements for Boni and Liveright's series proclaimed: "The 'Modern Library' appeals to people who consider good books a necessity, not a luxury. People are judged by the books they read" ("The Modern Library of the World's Best Books," original emphasis). Readers were promised that "the world's best books" would shape their taste and their personality. In short, advertisements for the Modern Library revealed the main characteristics of the new middlebrow ethos: the emphasis on education, the ideal of selfimprovement, and the explicit link between culture and social success.

Although Willa Cather has traditionally been seen as an elite writer who preferred "fewer readers and better readers" (WC to Greenslet, 31 Oct. 1932), recent scholarship has illuminated her involvement with a commercialized middlebrow culture. As Melissa Homestead points out, Cather "quietly exploited middlebrow institutions, such as book clubs and mass-circulation women's magazines, as a way to reach and engage the common reader" (78). Mark Madigan has shown that the Book-of-the-Month Club chose two of her books as main selections (Shadows on the Rock in 1931, and Sapphira and the Slave Girl in 1940), and recommended many of her titles as alternative choices for members who declined the main selection (72-79). In 1927, Death Comes for the Archbishop thus appeared in the alternative selection. Despite this increasing interest in Cather's participation in middlebrow culture, nobody has yet examined her involvement with the Modern Library.

In her article on the Armed Services Editions, Mary Chinery notes that, although Cather "was protective of her work and its publication in all forms" (287), she made an exception when reprints served the war effort. In fact, Cather had repeatedly allowed her works to be reprinted in cheaper editions well before the Second World War. As early as 1925, Knopf published Youth and the Bright Medusa in the Borzoi Pocket Book series and sold it for $\$ 1.25$ - a price dropped to $\$ 1$ when the second pocket edition was issued in 1929 (Crane 82-83). Cather approved of this inexpensive edition, and asked her publisher to send her six copies (WC to Aaron, 26 Apr. 1929). In 1926, Knopf issued a dollar edition of One of Ours, with an introduction by the Yale professor Stanley Thomas Williams. The book appeared in the Students' 
Library of Contemporary Fiction series, and targeted the academic market. ${ }^{4}$ In 1929 , Houghton Mifflin included $O$ Pioneers! in its own "dollar series," the Riverside Library. Cather later said that Houghton Mifflin had acted "without [her] consent, but eventually decided that this was not good policy and took the cheap edition off the market" (WC to Hench, 16 May 1940). Actually, Cather did authorize the Riverside Library edition of $O$ Pioneers!, in part to avoid a cheap edition of My Ántonia (WC to Greenslet, 3 Feb. 1929, 2 May 1932). But in May 1932, she started a campaign to eliminate all reprints of her works.

How can we account for Cather's increasingly hard line against cheap editions? My essay shows that Cather privileged her short-term economic interests over her long-term position in the literary canon. Because she was confident that the success of Death Comes for the Archbishop and Shadows on the Rock would increase the sales of her other titles, her objective was not to attract more readers, but to maximize the amount that each reader would spend. In other words, there was no need to decrease the price of a product for which there was plenty of demand. Although Cather gave many explanations to her opposition to reprints, she ultimately took a business decision to stop all cheap editions after receiving what she saw as disappointing royalty statements from Houghton Mifflin. This hostility to cheap editions contributed to her gradual marginalization in the literary canon, as instructors were reluctant to select more expensive, often illustrated, editions for their courses.

Drawing on extensive archival work in the Random House collection at Columbia University Library and other collections, ${ }^{5}$ this essay is organized into two parts. First, it shows the ways in which the Modern Library edition of Death Comes for the Archbishop was published, advertised, and sold to the academic market. The second part analyzes Cather's belated refusal to allow cheap editions of her texts, and the consequences of that decision on her place in the literary canon. ${ }^{6}$

When Bennett Cerf and Donald Klopfer bought the Modern Library from Horace Liveright in 1925, one of their first decisions was to add a title by Willa Cather in their series. In August 1925, Cerf wrote to Robert Linscott, then a junior editor at Houghton Mifflin, asking for the right to reprint $M y$ Ántonia in the Modern Library. If the title was not available, Cerf was ready to accept The Song of the Lark instead, "though this latter title is decidedly less desirable from our point of view" (Cerf to Linscott, 25 Aug. 1925). He offered a royalty of eight cents for the former title, and six cents for the latter. As Modern Library books were sold for ninety-five cents, there was not much room for higher reprint fees. Linscott immediately declined the offer: "the difficulty, of course, lies in the fact that the only books you want are those of permanent value which continue to have a steady sale in our regular editions, and the small prices that you are able to pay would not justify us in impairing this sale in any way" (Linscott to Cerf, 25 Aug. 1925). Linscott 
and his colleagues were certainly right to consider My Ántonia and The Song of the Lark as books of "permanent value" that would continue to sell over a long period of time-H. L. Mencken had famously presented My Ántonia as an American classic ("Mainly Fiction"). Their attitude towards Cather titles exemplifies the positioning of Houghton Mifflin, a "list" publisher that relied on its prestigious backlist to make profit over a long period of time (Feltes 28).

Unable to come to an agreement with Houghton Mifflin, Cerf and Klopfer turned to Alfred Knopf, who had been Cather's publisher since 1920. Initially, the new owners of the Modern Library found it hard to build a friendly relationship with Knopf. In his study of the Modern Library, Jay Satterfield notes that Knopf "detested Liveright and was hostile to the series from its inception" (138). Knopf deeply resented the fact that Liveright had reprinted W. H. Hudson's Green Mansions in the Modern Library without his permission and apparently without paying any royalty. Under the manufacturing clause in the international copyright agreement, the novel was unprotected in the United States. ${ }^{7}$ However, Knopf paid a voluntary royalty to the author and was infuriated at Liveright's more unscrupulous practices. After Liveright sold the Modern Library, Cerf and Klopfer "agreed to pay a small royalty to win [Knopf's] good graces" (Satterfield 138). But it was not until 1929 that the relationship between Knopf and the Modern Library owners started to become more cordial. In January of that year, Knopf agreed to sell the reprint rights of Carl Van Vechten's Peter Whiffle for ten cents per copy. Cerf was delighted, and suggested adding other Knopf titles to the Modern Library: André Gide's The Counterfeiters for eight cents per copy, and, for a ten cents royalty, Joseph Hergesheimer's The Three Black Pennys, H. L. Mencken's Selected Prejudices, and a Katherine Mansfield title. Cerf also asked for the reprint rights to Willa Cather's Death Comes for the Archbishop. For the latter, he was prepared to pay twelve cents per copy - a fifty percent increase over the royalty he had offered to Houghton Mifflin for My Ántonia (Cerf to Knopf, 30 Jan. 1929).

Despite Cerf's increased offer, Knopf was not ready to sell the reprint rights to Death Comes for the Archbishop. More than one year after its publication, Cather's novel continued to be one of the most successful titles on his list. According to Joan Crane, Knopf printed 86,500 copies of Archbishop in 1927 and 1928. By December 1928, eighteen printings had been completed (129-34). Even for less profitable titles, Knopf generally preferred to issue his own cheap editions than to negotiate with reprint series. Knopf's Borzoi Pocket Books series thus reprinted Youth and the Bright Medusa in a distinguished physical format. ${ }^{8}$ The cover of the 1925 pocket edition is made of dark blue leather embossed with a black design, and a green oval containing the publisher's logo. The title page was designed by Elmer Adler, a book designer that Cather particularly admired. ${ }^{9}$ In other words, Knopf made sure that the pocket edition did not look cheap. However, as Satterfield notes, Knopf's Borzoi Pocket Books series “lacked both the Modern Library's 
distribution system and advertising budget" (139). The same could be said of Knopf's Students' Library of Contemporary Fiction series, which included only three other titles when Cather's One of Ours was added to the list in 1926. Only books with significant appeal could turn a profit in Knopf's series. For titles that risked going out of print, such as Gide's The Counterfeiters, Knopf accepted to negotiate with the Modern Library, a series with a stronger commercial force. ${ }^{10}$

Death Comes for the Archbishop would probably never have been reprinted in the Modern Library without a mix of luck and determination on Bennett Cerf's part. In fall 1929, Knopf travelled to Europe and left his "very capable secretary" Manley Aaron in charge of the day-to-day business (Knopf, "Miss Cather" 211). Cerf contacted Aaron to renew his offer to reprint Archbishop with a first printing of 35,000 copies, corresponding to an advance royalty of $\$ 4,200$ at twelve cents per copy. He also offered ten cents per copy for Thomas Mann's The Magic Mountain, with a first printing of 30,000 copies (Cerf to Aaron, 19 Nov. 1929). These printing figures were unusually high for the Modern Library. For example, Van Vechten's Peter Whiffle had a first printing of 8,000 copies in the series. ${ }^{11}$ Cerf knew that Cather's and Mann's novels would be difficult to get, and he was prepared to offer a very large advance royalty. "There were no paperbacks in those days," Cerf later said, "and if you offered a $\$ 5,000$ guarantee for an old book, that was pretty snazzy" (Reminiscences, 4 Oct. 1967). Cerf pressed Aaron to reply "in a very short time," presumably in the hope of closing the deal before Knopf's return. Aaron then contacted Willa Cather, and obtained her approval for a reprint edition of Archbishop at six cents per copy for the author (the original publisher took half of the total royalty, as it was then customary). Knopf's secretary acted quickly, sending the contract to Cather only two days after Cerf's letter (Knopf Inc. to WC, 21 Nov. 1929). After many unsuccessful attempts, Cerf had finally secured a Cather title for the Modern Library.

It seems surprising that Cather, who had rejected a cheap edition of $M y$ Ántonia in 1928, accepted the Modern Library offer only one year later. Death Comes for the Archbishop was still selling briskly in its original edition. So why did Cather consent to a cheap edition, only two years after the first publication of the novel? Cather later wrote to Ferris Greenslet: "I let the book go into The Modern Library simply because I hated to be disobliging, and the result has been a very considerable money loss both to Alfred Knopf and to me" (WC to Greenslet, 31 Oct. 1932). Yet, it is hard to believe that Cather, who was notoriously strong-willed, would have signed a contract only for fear of being "disobliging" to Knopf's secretary. In a letter to Alexander Woollcott, Cather gave another version of the story:

About twelve years ago, when Mr. Knopf was in Europe, the Modern Library people came to one of the employees in the office and urged her to give 
them the right to republish one of my books three years from that date. She telephone [sic] me to get my consent. I was living at the Grosvenor Hotel: I was writing another book, and three years seemed a long way ahead. I gave the young woman my consent and hung up the telephone. The result was that I lost a good deal of money, since the Modern Library pays a royalty of only six cents a copy. (WC to Woollcott, [4 Dec. 1943?])

In fact, Bennett Cerf had proposed to publish Archbishop in spring 1931: not three years, but only one year and a half from the date of his offer. The contract sent by Knopf's secretary specified that the publication would be in early fall 1931. Cather did not simply gave her oral agreement to a reprint in the Modern Library, she signed a document knowing that the book would be published in two years. Cather may even have negotiated the delay in the publication of the cheap edition, from spring to fall 1931. Although she would later regret her decision, it is likely that Cather was favorably impressed by the 35,000 copies guaranteed by the Modern Library. The month when she accepted the Modern Library offer, the Knopf edition of Archbishop went through its twenty-second printing, consisting of 1,000 copies (Crane 134). It seems that Cather saw the Modern Library edition as a way not only to broaden the audience of the book, but also to immediately obtain an advance royalty of $\$ 2,100$ - around $\$ 28,200$ in 2013 dollars.

The publication of Death Comes for the Archbishop in the Modern Library coincided with the release of Cather's new novel, Shadows on the Rock. The timing could not have been better. While many publishing enterprises struggled with the Depression, the Modern Library flourished thanks largely to its cheap price. As Gordon Neavill notes, "by the early 1930s the Modern Library was selling a million books a year" (135). In July 1931, Publishers" Weekly announced that one of the Liggett drug stores in New York was having good success with its Modern Library window display ("Sales Notes"). For booksellers who were interested in creating their own display, the set-up and signs were available free of charge. The main focus of the display was on the price of Modern Library books, a price repeated on every sign. The new, brightly colored pictorial book jackets made the window display particularly attractive. Finally, the uniformity of the series was emphasized with the slogan: "each one a gem!" Modern Library books were thus marketed as both cheap and distinguished. Two weeks after announcing the Modern Library's new window displays, Publishers' Weekly carried an advertisement for Shadows on the Rock, presented as a letter to booksellers (Shadows on the Rock). In this letter, Alfred Knopf made a parallel between Cather's new novel and Death Comes for the Archbishop, which had sold 96,756 copies in its original edition. Knopf also declared that the new novel had been selected by the Book-of-the-Month Club and the Catholic Book Club, with a total printing of 51,800 for the two clubs. ${ }^{12}$ The first trade printing was 25,000 , with a second printing of 38,200 in preparation. As in earlier advertisements for Archbishop, the repetition of 
printing figures conveyed the impression that Cather's novel would be an exceptional bestseller. "I think this novel may outsell even [Warwick Deeping's bestseller] Sorrell and Son and I seriously doubt if a more salable or a better novel will be published this year," wrote Knopf, thus presenting Cather as a writer who combined commercial appeal and literary quality.

Knopf's publicity push helped the launch of the Modern Library edition of Cather's novel. "Our advance sale on Willa Cather's Death Comes for the Archbishop is the largest we have ever had on a Modern Library book," Cerf wrote. "We are looking forward to a big Fall." ${ }^{13}$ Part of the appeal was that the Modern Library edition was to be the only cheap edition, as Cerf told one of his sales representatives (Cerf to Smalley, 2 July 1931). On August 1, 1931, the day when Shadows of the Rock was published, the Modern Library ran an advertisement announcing its new titles for the fall. Archbishop was first on the list, and The Magic Mountain was last. Other titles included Wells's Tono-Bungay and Balzac's Droll Stories. This was arguably one of the most appealing lists that the Modern Library had ever issued (Tono-Bungay and Droll Stories continued to sell for forty years in the series). In the following weeks, as Knopf pursued his efforts to promote Shadows on the Rock and bookstores arranged window displays of the novel, Cerf widely advertised Archbishop. His marketing strategy, largely inspired by Knopf, relied on two central elements: first, the reproduction of Harold Von Schmidt's drawing of the bishop on horseback functioned as a brand identifier and ensured product recognition; second, Death Comes for the Archbishop was often singled out as an exceptional new addition, in contrast to traditional advertisements for the Modern Library that emphasized the uniformity of the series, rather than the individual qualities of each book.

Always a savvy businessman, Knopf used cutting-edge marketing strategies to sell modern literature to a mainstream audience. As Catherine Turner points out, he strived to make the Borzoi device into "a trademark that could be counted on to guarantee a book worth reading" (92). Amy Root also suggests that "the genuinely distinctive aspect of a Borzoi book was Knopf's masterly use of book production as book promotion." The Borzoi label "appeared not only on cases, jackets, and title-pages but also in varying colors on endpapers" (505). The Borzoi logo unified Knopf's list, emphasizing the books' common physical appearance and aesthetic quality. As Turner notes, Knopf once ran "a series of advertisements for the Borzoi imprint that did not use the titles of any Knopf books at all" (92). For Archbishop, however, Knopf felt the need to combine the Borzoi device with a logo that would apply only to the novel. Judging from the advance sales, Knopf believed that Archbishop was bestselling material, and he did his best to create an instantly recognizable product. In addition to the Borzoi logo, advertisements for Archbishop reproduced Von Schmidt's drawing, thus creating a cognitive association between the illustration and the novel. ${ }^{14}$ Von Schmidt had designed 
the illustrations for the serialization of the novel in the Forum (Crane 129), and the drawing of the bishop also appeared on the dust jacket of the first edition (Figure 1). ${ }^{15}$ Bennett Cerf deeply admired Knopf's merger of branding and book design. "Borzoi books were my dream of the way books should look," he later said (Reminiscences, [1967]). It is hardly surprising, therefore, that Cerf imitated Knopf's book production and advertising, with Von Schmidt's drawing appearing on the dust jacket of the Modern Library edition (Figure 1) and on nearly all advertisements. Four years after the first publication of Archbishop, it would have been difficult for any literate American to remain unaware of Cather's novel, a novel that had its own logo reproduced on dust jackets and advertisements.

As a uniform series, the Modern Library generally made no distinction between its titles. Advertisements and promotional materials presented all Modern Library books as equally good and worth reading ("each one a gem!"). Instead of singling out a specific book, advertisements featured lists of titles, either new additions or popular books in the series. Cerf did not entirely abandon this approach with the launch of Cather's novel. One advertisement thus featured three new Modern Library Giants, alongside the two September additions to the regular list-Death Comes for the Archbishop and A History of the Borgias ("The Modern Library Series," 12 Sept. 1931). But Cather's novel was also presented as an extraordinary Modern Library book, as evidenced in
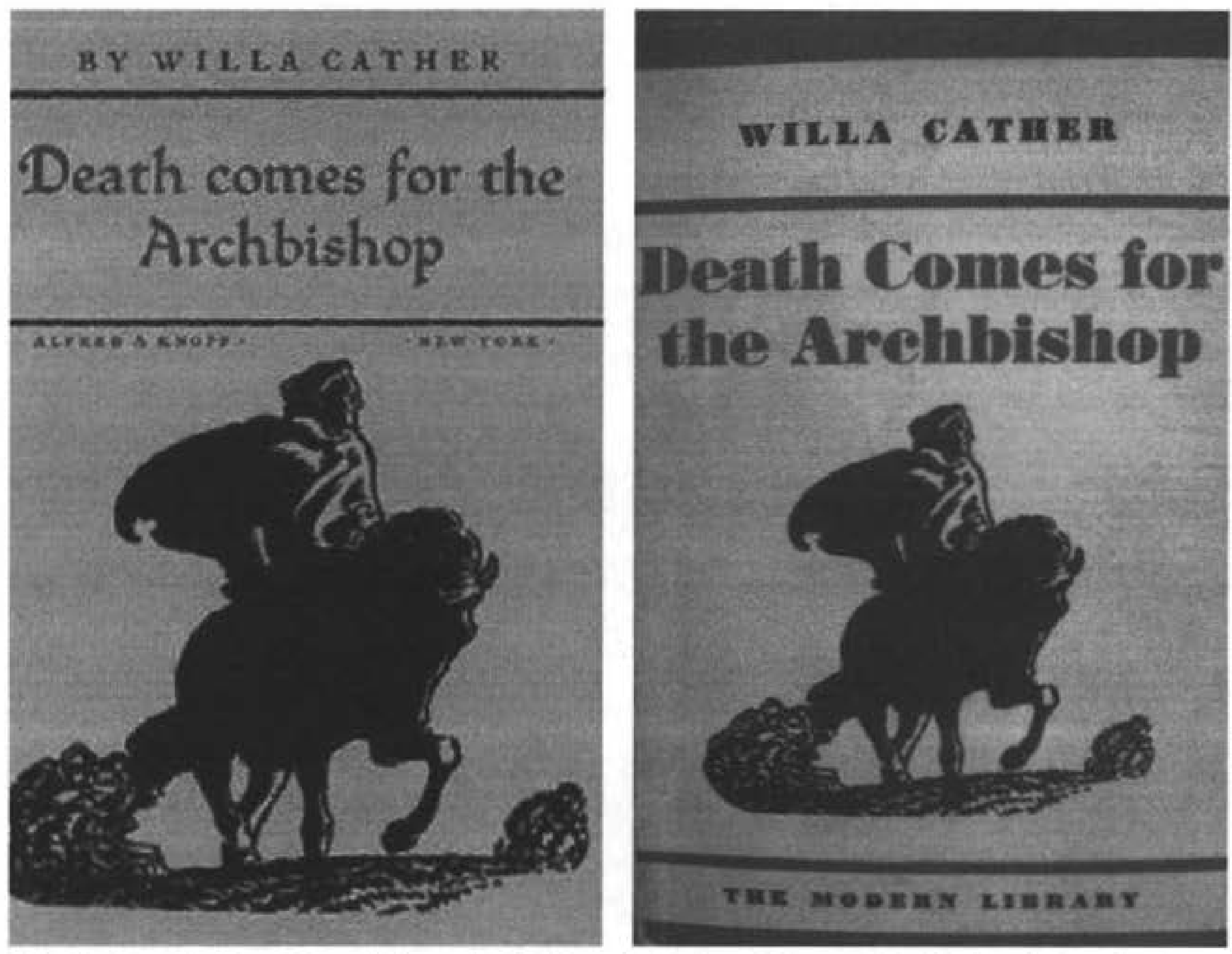

Fig. 1: Dust jackets, Knopf first ed. (left) and Modern Library ed. (right) of Death Comes for the Archbishop. 
the reproduction of its own logo. Like Knopf, who had marketed Archbishop as a unique product within the Borzoi Books series, ${ }^{16}$ Cerf underscored the exceptional quality of Cather's novel within the Modern Library series. Never before had such an emphasis been placed on a single Modern Library book. In one advertisement in the Virginia Quarterly Review (Figure 2), the focus was on "Willa Cather's famous novel" rather than the Modern Library brand. The title of the novel appeared in large, eye-catching type, below a reproduction of Von Schmidt's drawing. Other titles were listed in the ad as well, but in much smaller type and without illustrations. If each Modern Library book was a "gem," Death Comes for the Archbishop was undoubtedly the series' most precious addition.

While reprints were rarely reviewed in periodicals, the publication of Death Comes for the Archbishop in the Modern Library was sufficiently exciting to attract the attention of several reviewers. In his column in the North American Review, Herschel Brickell presented Cather's novel as "already... a classic, a fate it deserves, and richly." For Brickell, "careful buyers will do well to keep an eye on the Modern Library lists; they pay dividends" (473). This financial vocabulary highlighted the growing reputation of Cather. Like a sought-after stock, Cather had seen her value rise in the literary market. The Deseret News, a newspaper based in Salt Lake City, also celebrated Cather's growing status. "When Death Comes for the Archbishop was first published some four years

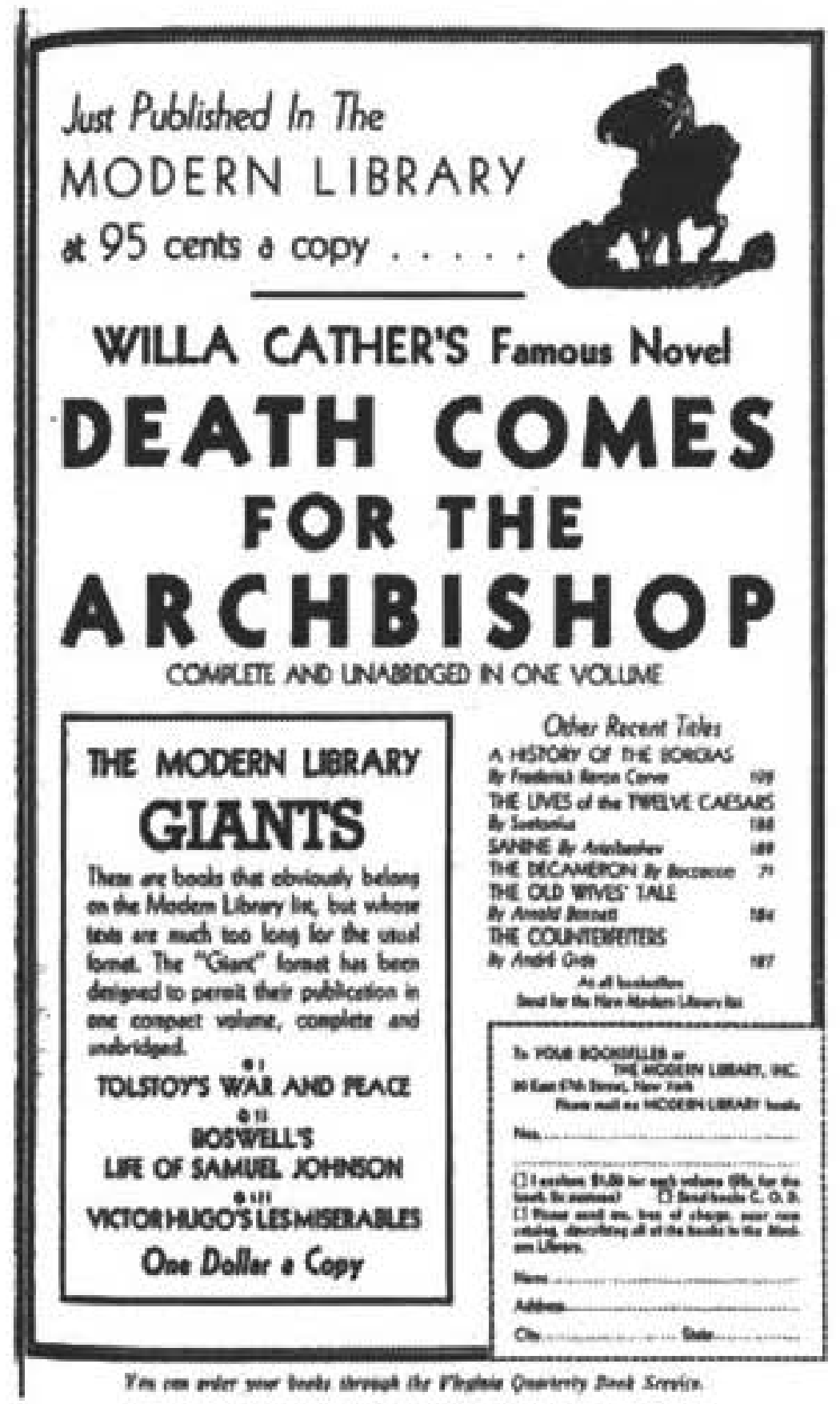

Fig. 2: Ad for the Modern Library, Virginia Quarterly Review Oct. 1931: n. pag. ago, it won its authoress, Willa Cather a high place among contemporary literary artists of America," declared the Deseret. "The book has now reached its logical position in space by being selected as one of the latest additions to the Modern Library series" ("Cather Book"). For the Deseret, Cather had seen her reputation rise so much that Archbishop was now included in a series of classics, just four years after its publication. ${ }^{17}$ Like all other Modern Library books, Archbishop was marketed as a classic that deserved its place among the "world's best books." Many professional and common readers agreed with this categorization: for them, Cather's novel belonged to the emergent canon of American literature.

In November 1931, shortly after the publication of the Modern Library edition of Archbishop, the English Journal announced that the College 
Entrance Board had selected Cather's novel as a text for high school students to prepare (Miller 722). Although no specific edition was mentioned, the vast majority of students and their instructors would have chosen the cheapest on the market. With five dollars, one could buy five copies of the Modern Library edition, and only two copies of the Knopf edition of Archbishop. The owners of the Modern Library strived to increase their share of the high school market by advertising in teachers' periodicals. One advertisement in the Scholastic magazine, the national high school weekly, thus listed Cather's novel among the "ten best sellers in the Modern Library." Other titles included older classics like Dostoyevsky's The Brothers Karamazov, Thackeray's Vanity Fair, and Melville's Moby Dick, as well as recent works such as Hemingway's A Farewell To Arms. These Modern Library books "will provide the nucleus for a personal library that you can be proud of," declared the ad ("The Modern Library Series," 28 Oct. 1933). With the inclusion of Archbishop in the Modern Library, and the decision of the College Entrance Board, it was clear that Cather had the institutional support necessary to her long-term survival in the literary canon.

The Modern Library targeted not only the high school market, but also college instructors and their students. Textbook publisher F. S. Crofts was initially handling Modern Library sales in the college market. When Crofts failed to achieve significant results, Cerf took over college marketing. In 1932, he asked a consultant to prepare a series of form letters to university bookstores and departments. The Random House archives contain the drafts prepared by the consultant and the final versions edited by Cerf. ${ }^{18}$ These letters insist on the fact that, unlike Everyman's Library, the Modern Library was "manufactured entirely in the United States," allowing for immediate delivery "on all orders of reasonable size." The diversity and modernity of the Modern Library were also presented as selling points: "Volumes in the Modern Library appeal to modern students as the range of titles included in the series is so diversified, that the student may supplement the books he is required to read with books uniform in makeup, yet perhaps more characteristic of his individual taste in reading." In the letter to contemporary literature departments, Cerf offered suggestions of Modern Library titles suitable for classroom use, including Arnold Bennett's Old Wives' Tale and Willa Cather's Death Comes for the Archbishop. At the time when few literary scholars specialized in the twentieth century, Cather's novel was already marketed as a classic that deserved to be taught in university courses.

Cerf's marketing strategy also involved convincing college bookstores to stock the Modern Library. In 1936, editorial copy was secured in the College Store, the National Association of College Stores' trade magazine, as free publicity in connection with an ad that the Modern Library was running in the magazine (Satterfield $192 \mathrm{n} 25$ ). The magazine invited booksellers to prepare gift boxes with several Modern Library titles grouped around a common theme, 
such as modern literature: "There are books by Sinclair Lewis, Willa Cather, James Joyce, Ernest Hemingway, Gertrude Stein, Aldous Huxley, Marcel Proust, for students who feel that they must read the very latest authors or tag themselves as behind the times" ("A Modern Interview"). Although courses in modern literature were still rare in the 1930s, it was part of the Modern Library's marketing strategy to stress both its seriousness and its timeliness. Students of English literature might have used a Modern Library edition of Chaucer's Canterbury Tales, and then browsed the shelves of their college bookstore to find Death Comes for the Archbishop and other modern classics.

From 1931 to 1936, at the time when Cather's novel was available in the Modern Library, the study of American literature was being institutionalized in university departments. As Kermit Vanderbilt and others have shown, the first two decades of the twentieth century saw a rise of academic interest in American literature. In March 1929, the first scholarly journal dedicated entirely to American literary studies, American Literature, published its first issue. It included a review of T. K. Whipple's Modern Writers and American Life, which discussed Willa Cather among other contemporary American writers (Mitchell and White 108). In the late 1920s and early 1930s, Cather often received letters from academics interested in her work, and she in turn commented on the reception of her work in academia. For example, she wrote to the well-known author and professor Burges Johnson that most academic critics lack sound judgment: "Their idea of being scholarly is to be as far as possible from common sense" (WC to Johnson, [1928?]). Cather's correspondence with one instructor, shortly after the publication of Archbishop in the Modern Library, also highlights her ambiguous attitude towards the academic study of literature. Cather was uneasy with assignments of her novels in literary courses: "If young people read me, I would like it to be because they want to." Yet, she also wrote: "If one of my books has to be read year after year (as Ivanhoe was in the days when I went to school), I think that Death Comes for the Archbishop will stand the wear and tear better than the others" (WC to Meromichey, 5 Oct. 1931). This was coherent with Cather's early statement that Archbishop would be her most enduring work. ${ }^{19}$ At this point, Cather seemed quite content to accept the growing status of Archbishop in the school system, and to encourage the dissemination of her novel in the Modern Library edition.

Although we do not know how many copies of Archbishop the Modern Library sold to the education market, the availability of a cheap edition undoubtedly incited instructors to add the novel to their syllabi. Printing figures give a sense of the overall success of the title in the series. According to Gordon Neavill, the Modern Library ordered a first printing of 15,000 copies, followed by a second printing of 10,000 copies (244). Crane references a total of four Modern Library printings (in September 1931, November 1931, December 1932 , and July 1933) (134-35). ${ }^{20}$ If it were true, it would mean that the Modern 
Library did not reprint in the last three years before the title was discontinued. After the initial success, such a drop in demand is of course highly unlikely. In fact, there were at least three more printings. In March and October 1934, the Modern Library ordered two printings of 5,000 copies each, followed by a large printing of 15,000 copies in June 1935. In February 1936, Knopf Inc. sent an invoice for a printing of 15,000 copies. ${ }^{21}$ Although there is a possibility that this was a late invoice for the June 1935 printing, it is more likely that it applied to a new printing made in early 1936 . This would be coherent with the letter that Alfred Knopf sent to Donald Klopfer in June of that year: "I know you have quite a stock on hand of the ARCHBISHOP, yet I have been hoping that you would see your way clear to discontinuing its sale after September 25 th" (Knopf to Klopfer, 9 June 1936). Klopfer responded that they had 8,000 copies in stock, "or about a six months' supply" (Klopfer to Knopf, 10 June 1936). In total, the Modern Library printed approximately 65,000 copies of Death Comes for the Archbishop in five years.

Cather closely monitored the performance of the Modern Library edition, fearing it would affect the sales of the more expensive edition. In June 1933, Blanche Knopf told her that the Modern Library edition had sold 28,750 copies so far (Blanche Knopf to WC, 6 June 1933). As late as 1946, Cather continued to track the sales figures of Archbishop, undoubtedly because she was still worried about the long-term negative effects of the cheap edition. Her publisher reported sales of 59,000 in the Modern Library, 106,195 in the Knopf trade edition, and 26,681 in the illustrated edition (Knopf Inc. to WC, 10 Dec. 1946). The Modern Library edition sold more than twice as many copies in five years as the illustrated edition did in ten years. ${ }^{22}$ Even compared to other Modern Library titles, Archbishop was an impressive success. ${ }^{23}$

The story of Cather's attitude towards reprints is one of growing resistance, from pragmatic attitude to stubborn opposition. Writing from a later standpoint, Alfred Knopf mentioned only the uncompromising stance of her last years. "She never wanted any kind of cheaper editions of her books," declared Knopf. "She felt that they would be used in schools and colleges and that boys and girls would grow up hating her because they had been compelled to read her" ("Miss Cather" 211). Yet, as we have seen, Cather was initially willing to recommend Death Comes for the Archbishop for classroom use at a time when a cheap edition was readily available. In December 1931, she even planned to offer the Modern Library edition of Archbishop as a Christmas present (WC to Blanche Knopf, 16 Dec. 1931).

Only five months later, however, she began a campaign to end all reprints of her work. So what happened? Why did Cather suddenly change her mind about cheap editions? The trigger seems to have been a royalty statement that showed a sharp decrease in the sales of the regular edition of $O$ Pioneers! following the publication of a cheap reprint in the Riverside Library. In a 
letter to Ferris Greenslet, she asked that Houghton Mifflin adjust her rate of royalties to compensate for the loss (WC to Greenslet, 2 May 1932). At this point, Cather had made up her mind that cheap editions profited the publisher rather than the author. Even if the cheap edition was successful, the meager royalties paid for each reprinted copy did not make up for the decreasing sales of the original edition. Shortly after contacting Greenslet, Cather asked Knopf to discontinue the contract with the Modern Library (since she had signed for five years, it was not done until 1936) ${ }^{24}$ She also complained that, despite her efforts to eliminate all cheap editions, the British publisher Jonathan Cape had just included The Song of the Lark in the Travellers' Library series (WC to Greenslet, 17 July 1932).25

Cather's publishers had various reactions to her new radical opposition to reprints. While Alfred and Blanche Knopf agreed that the Modern Library had meant a loss of income for all of them, ${ }^{26}$ Ferris Greenslet tried hard to convince Cather of the benefits of cheap editions. The Riverside Library edition of $O$ Pioneers! was undoubtedly advantageous to the publisher. Unlike Knopf Inc., which received a share of the royalties paid by the Modern Library, Houghton Mifflin did not depend on an external series of reprints. Moreover, Houghton Mifflin offered only a five-cent royalty to Cather (Knopf paid twice that amount for the cheap edition of Youth and the Bright Medusa). ${ }^{27}$ Greenslet rejected Cather's request to increase the royalty rate, and, in an effort to prove that the cheap edition had been beneficial to all interested parties, he sent her a complete statement of her income for $O$ Pioneers! from 1913 to 1931 (Figure 3). This statement shows a three-part evolution. Cather's royalty income plummeted in the first two years following the publication of the book, and remained low until 1918. Following the publication of My Ántonia, royalties for $O$ Pioneers! increased steadily and peaked in 1929 (the year when the cheap edition was published). In a third phase, Cather's royalty income decreased sharply and, in 1931, had returned to its 1927 level. Greenslet underscored the difficult economic context, and reminded Cather that the cheap edition had enlarged her audience (even if her royalty income had not increased): "I think it is better for an author, take it by and large, to earn $\$ 200.00$ a year from the sale of three or four thousand copies of a book rather than the same amount per annum from the sale of a thousand" (Greenslet to WC, 17 May 1932). After Cather repeated her request to withdraw the Riverside Library edition, Greenslet emphasized the moral issue of democratization, reminding the author that it would be "a blow to the more impecunious section of the public, which is rapidly increasing in proportions" (Greenslet to WC, 2 June 1932). 


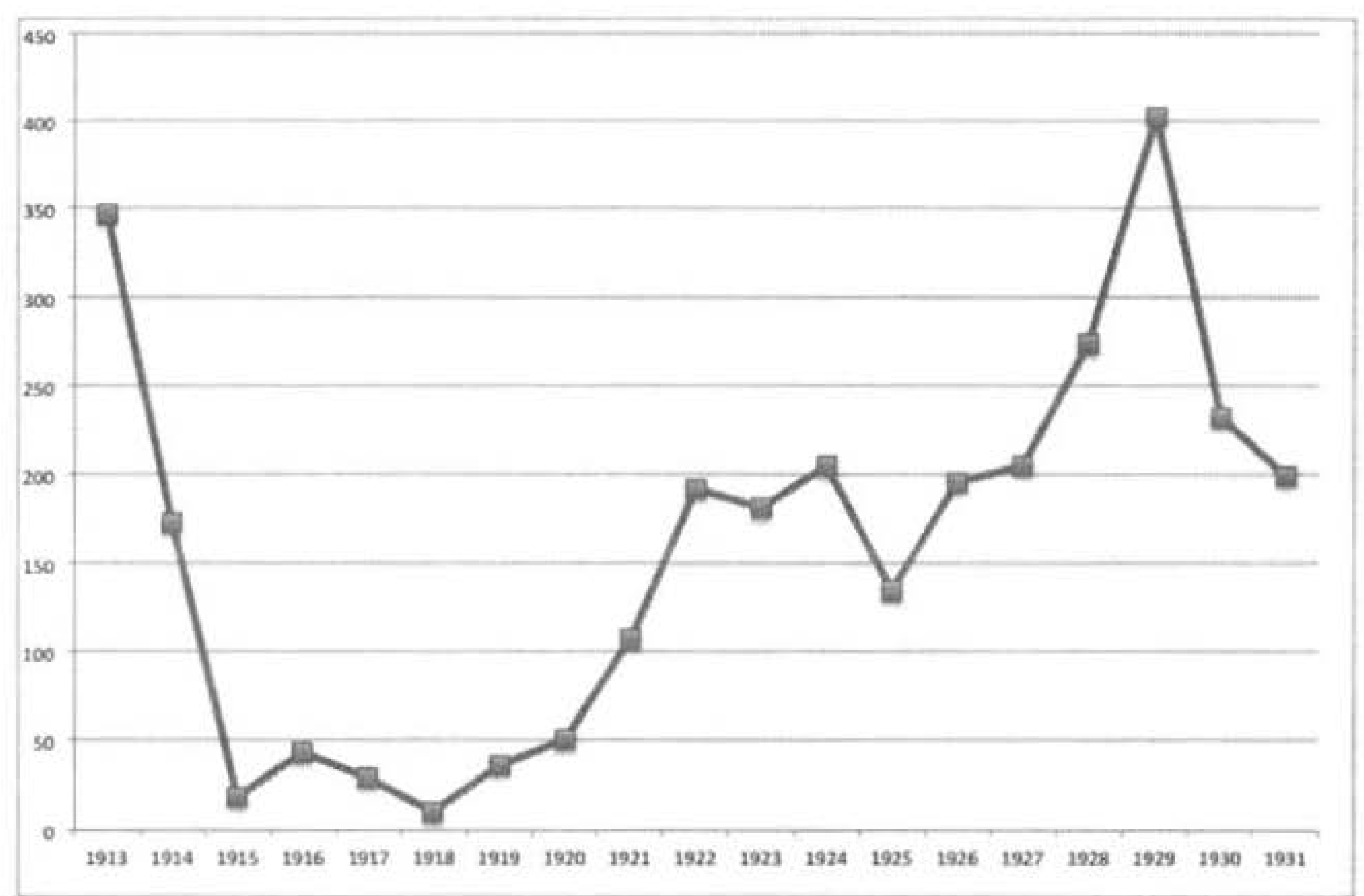

Fig. 3: Cather's Royalty Income (in \$) for O Pioneers!, 1913-1931.

Undeterred by Cather's hostility against reprints, Greenslet repeated his offer to issue My Ántonia in a cheap edition, alongside Shadows on the Rock and Death Comes for the Archbishop (Greenslet to WC, 21 Oct. 1932). For Cather, this was out of the question: "My whole preference is to sell a few books and to make a dignified royalty on them; to have fewer readers and better readers" (WC to Greenslet, 31 Oct. 1932). It is clear that Cather's motivation was mainly, but not only, economic. An expensive edition meant a higher royalty rate, which was good not only for her bank account but also for her reputation. For Cather, a "dignified royalty" (note the vocabulary of taste) led to an increase in symbolic capital (Bourdieu), since it signaled a refusal to compromise with the mass market. In response to her editor's plea for poor readers, Cather constructed an elitist discourse that valued quality over quantity. She thus downplayed her main reason for withdrawing the cheap edition (i.e., her dissatisfaction with the low royalty rate) and focused instead on the issue of taste to position herself as an author of quality fiction for sophisticated readers.

Was Cather right to see cheap editions as a bad deal for the author? For the first edition of Death Comes for the Archbishop (sold for \$2.50), she received a 15 percent royalty rate on the first 50,000 copies, and 16 percent $(40$ cents per copy) thereafter. ${ }^{28}$ That was more than six times what she got from the Modern Library. At first sight, it seems that Cather did lose money on the Modern Library deal. During the time the book was available in the series, Knopf reprinted only 6,300 copies of the first edition, an average of 1,260 a year (Crane 135). But it is important to put these figures in perspective. When the Modern Library edition was published, four years after the first edition, the demand for the $\$ 2.50$ edition 
had already dropped (Figure 4). ${ }^{29}$ The cheap edition revived interest in a title that was yesterday's bestseller. From 1931 to 1936, Cather received a total of at least $\$ 6,060$ in royalties for Archbishop: $\$ 2,520$ for the first Knopf edition and a minimum of $\$ 3,540$ for the Modern Library edition. If the Modern Library edition had not been available, Knopf would have had to sell 15,150 copies of the first edition in five years for Cather to receive the same royalty income. This might have proved unfeasible, considering the declining demand for this edition. The Modern Library probably allowed Cather to earn more than she would have if the book had only been available in the $\$ 2.50$ edition.

Cather worried not only about her royalty rate, but also about the kind of public that bought the cheap edition. When one instructor asked her why the Modern Library edition was no longer available, Cather started by giving yet another version of her decision to allow a reprint edition (WC to Hench, 16 May 1940). A few years after the publication of Death Comes for the Archbishop, Cather said, "many urgent appeals came from schools and even from book sellers for a cheap edition of the book." She then "consented that an employee of Mr. Knopf's office should make a five-year contract with the Modern Library to publish a cheap edition for poor students." After positioning her story in the setting of the school, with students as characters, Cather went on to explain her loss of royalty income and her subsequent decision not to renew the contract with the Modern Library: "when the five-year contract expired I felt that I had done my duty by the poor student." Of course, that meant that young people now had to pay a lot more to buy the only available edition of Archbishop. Cather claimed not to be bothered by that: "when a student really wants a book he can always manage to buy it," for example by paying by installments as she herself had done when she was at school. For Cather, a cheap edition risked

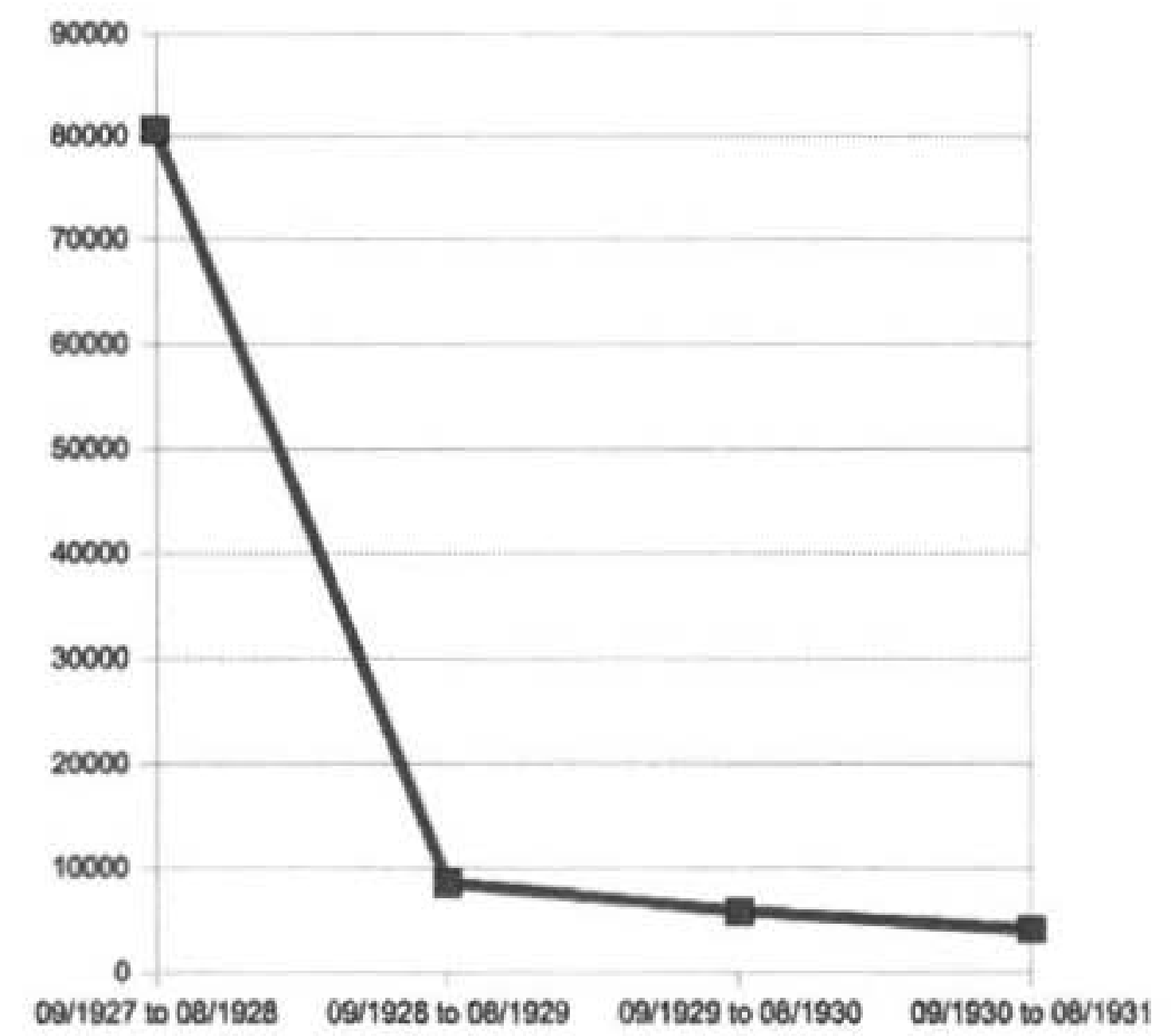

Fig. 4: Printing Figures, Knopf first ed. of Death Comes for the Archbishop (Crane 129-35). 
attracting the wrong kind of readers: those who had to read the book as an assignment, and those who lacked any real commitment to her fiction.

Cather decided to end all reprint editions of her works in May 1932, one year and a half before Granville Hicks published his now-famous attack against her in the English Journal. However, Hicks and other Marxist and liberal critics had already developed their arguments in earlier articles. "Miss Cather... has always been soft; and now she has abandoned herself to her softness," wrote Hicks shortly after the publication of Shadows on the Rock ("Bright Incidents"). For this school of criticism, Cather's latest novels revealed her passivity by refusing to engage with contemporary social issues, and retiring to a comforting past. Yet, many young reviewers did not share Hicks's assessment of Cather as a "minor artist." For Lodwick C. Hartley, a twenty-six-year-old poet and academic, Archbishop was "a superb product of her highest genius" (103). ${ }^{30}$ Hartley wrote in the Sewanee Review, a periodical that became instrumental in disseminating a new kind of university-based criticism with roots in the Agrarian movement. In the early 1930 s, Cather's regionalism fit well with this new critical movement. "There is no doubt that Miss Cather is the greatest of our provincial novelists, and her province is the world," wrote Kenneth C. Kaufman in the Southwest Review.

The young critics and academics that continued to admire Cather's writings were eager to educate a new generation of readers to appreciate her work, thus ensuring the continuous renewal of the customer base for her books. Yet, Cather refused to help them, clinging firmly to her refusal to issue cheap editions for "the poor student." Her hostility against cheap editions had nothing to do with a hostile critical climate. On the contrary, her correspondence shows a confidence in her ability to continue to attract readers in the long run. When she wrote to Ferris Greenslet to ask that the cheap edition of $O$ Pioneers! be discontinued, she had just published two bestsellers. She told him that the success of Death Comes for the Archbishop and Shadows on the Rock ought to increase the sales of the regular edition of $O$ Pioneers!: "The people who are enthusiastic about those two books will go back and hunt up the earlier books" (WC to Greenslet, 31 May 1932). At fifty-eight years old, Cather knew she had reached the peak of her career. There was simply no need to decrease the price of books if the demand was high and showed no signs of slowing down.

Cather's opposition to cheap reprints partly explains her declining critical reputation in the 1930s. Although there was probably nothing she could do to convince Hicks and his fellow critics that she was a major artist, she could have reached out to all those who wanted to teach her work to students. As Kevin Dettmar has argued in another context, some writers (or their agents or estates) view "literary reputation as something like a stock market, driven by investor confidence" and therefore decide "that the best long-term investment strategy is to balance short- and medium-term profitability with protection of the brand, by making one's work, or the work for which one is responsible, 
available." These writers are "investing for the long-term by letting [their] work be reprinted comparatively cheaply, knowing that securing a place in the canon will pay long-term dividends in both prestige and income." Cather did the exact opposite. She chose to maximize her royalties in the short-term by authorizing only expensive editions, and neglected her long-term reputation. Perhaps because she was not interested in the long-term canon, she failed to acknowledge that cheap reprints and anthologies would give a taste of her fiction to young readers, thus opening new markets in the future.

When the contract for the Modern Library edition of Archbishop ended in 1936, Bennett Cerf and Donald Klopfer were deeply disappointed to have to remove the title from their list. "Both Bennett and I feel very strongly that we would do anything within reason to renew this contract with you," wrote Klopfer to Knopf, "but as you have explained how Miss Cather feels on this subject, there doesn't seem to be anything more to say" (Klopfer to Knopf, 10 June 1936). In the mid-1930s, Cather was still considered one of the most important American writers and having to drop her from the Modern Library list meant not only a loss of profit opportunities, but also a loss of credibility for a series marketed as "the world's best books."

From 1937 to Cather's death in 1947, no new cheap edition of her work appeared in the United States (apart from the book club edition of Sapphira and the Slave Girl and the Armed Services Editions, distributed free of charge to soldiers). During the war, Cerf renewed his offer to publish My Ántonia in the Modern Library (Cerf to Dale Warren, 13 Sept. 1943). His request, which had been pending for nearly twenty years, became something of a joke at Houghton Mifflin. "Right now I am snatching a little time from the work which absorbs my every waking minute, i.e., making My Ántonia available to the Modern Library," wrote the editor Dorothy Hillyer (Hillyer to "Trade Wind" [Cerf], 8 Nov. 1943). No more titles by Cather would appear in the series before its demise three decades later. Cather continued to reject requests for paperback editions and anthologies, including a Portable Willa Cather proposed by Viking. ${ }^{31}$ Since the Portable series was sold to the academic market and contributed to the revival of interest in William Faulkner, Sherwood Anderson, F. Scott Fitzgerald, and others, Cather's decision seemed particularly shortsighted. Knopf pointed out to her that refusing reprints was highly unusual: "You would be amazed at how many authors who ought to know better feel actually flattered when they are included in an anthology, and often write the publisher warning him not to charge too large a fee for fear the editor will use something else instead" ("Miss Cather" 220). Here, Knopf underlined two opposite attitudes towards reprints: unlike most writers, Cather did not view reprints as a long-term investment beneficial to the author. At the time when Viking's Portable, the Modern Library, and other publisher's series benefited from the unprecedented expansion of the university system, Cather refused to exploit these institutions to broaden her audience. 
From the 1950 s to the 1970 s, Cather attracted less scholarly attention than Ernest Hemingway, F. Scott Fitzgerald, and Theodore Dreiser, as shown by the number of articles, books, reviews, and theses about them listed in the MLA Bibliography. Although there were more entries for Cather than for any of those writers in the 1940s, the trend reversed from the 1950s onwards (Appendix, Fig. 5). A comparison between Cather and Fitzgerald is helpful to highlight the role of reprint publishers in shaping the canon. In the mid-1930s, Fitzgerald's reputation was at its lowest point: the 1934 Modern Library edition of The Great Gatsby had to be remaindered five years later, having sold fewer copies than its first printing of $5,000 .^{32}$ This failure shows that reprint publishers could not single-handedly create a demand for a writer that no longer had any currency in academia. After Fitzgerald's death in 1940, a change of critical context made his work attractive to a new generation of scholars. James L. W. West thus describes The Great Gatsby as "a very teachable gem of a novel," "which in form and language fell perfectly in line with the concerns of the postwar New Critics" (98). The new demand for Fitzgerald's work was encouraged by the availability of reprint editions: in the mid-1940s, The Great Gatsby appeared in Viking's Portable series, in a New Directions hardcover edition, and in a Bantam paperback edition. An increasing number of academics researched and taught Fitzgerald's novel. Although Fitzgerald had been less studied than Cather in the 1940s, this changed dramatically in the 1950s, when there were twice as many books, articles, reviews, and theses on Fitzgerald than on Cather. The problem was not the critical climate: after all, Cather continued to attract scholarly interest, even if the growth of this scholarship was well below that of other American writers. Had Cather authorized a Viking's Portable edition of her work, had she let the Modern Library continue to reprint Death Comes for the Archbishop, had she embraced the paperback revolution, there is little doubt that she would have experienced a stronger revival after the war.

In the 1950s and 1960s, Knopf was deeply aware that Cather's decision to forego reprints had resulted in declining sales. In 1956, he decided to issue a paperback edition of Cather's stories under the Vintage imprint. As he often did, Knopf addressed a letter to readers in advertisements for the book:

I doubt that a great many of the young are now reading her. She felt that good books (and she included hers) were worth what they cost and frowned on cheap reprints. She believed the young should read her because they wanted to and not because a course at school or college required them to, so she forbade text book editions of her work. But had she lived to see them, I believe she would have welcomed today's superior paper backs. (Five Stories)

The arrival of "superior paper backs" in the mid-1950s was indeed an innovation that Cather did not live to see. Would it have changed her attitude towards reprints? This is highly unlikely, considering Cather's firm opposition to quality series such as the Modern Library and Riverside Library. However, 
Edith Lewis, Cather's literary executor, did authorize the paperback edition of Five Stories and, five years later, of My Mortal Enemy. The latter was reviewed in the New York Times by the critic Brooks Atkinson. "Today Willa Cather (1876-1947) is very much the major American writer," Atkinson wrote. He described Cather as "a scrupulous craftsman," whose books had aged better than Sinclair Lewis's Main Street and Babbitt and Ernest Hemingway's The Sun Also Rises.

Yet, it was only in the 1970 s that Cather started regaining a more dominant place in the literary canon. The number of academic books, articles, and theses on Cather thus doubled in the 1970s, compared to the previous decade (Appendix, Fig. 5). This increased scholarly interest was not only due to the rise of feminist and gender studies, but also to the availability of new paperback editions of Cather's works. New critical approaches increased the market for Cather titles, and, in turn, the availability of new paperback editions led more instructors to teach and study the novels. While Vintage published only two paperback editions of Cather's works in the 1950s and 1960s, the publisher then released Death Comes for the Archbishop (1971), One of Ours (1971), Shadows on the Rock (1971), A Lost Lady (1972), The Professor's House (1973), Obscure Destinies (1974), Sapphira and the Slave Girl (1975), Youth and the Bright Medusa (1975), The Old Beauty and Others (1976), and Lucy Gayheart (1976). A paperback edition of Alexander's Bridge also appeared under the University of Nebraska Press/Bison imprint in 1977. The rise in scholarly (and teaching) interest in Cather in the 1970s highlights the value of paperbacks in canon formation.

In the 1980s and 1990s, many Cather titles entered the public domain in the United States, which attracted the interest of an increasing number of reprint publishers. ${ }^{33}$ In 1989, for example, Penguin, Signet, and Bantam issued $O$ Pioneers! in paperback form. The Oxford World's Classics series published its first Cather title, Alexander's Bridge, in 1997, followed by O Pioneers!, Song of the Lark, and My Ántonia. It is now easy to find a variety of cheap editions of Cather's work (including Death Comes for the Archbishop, which is still copyrighted but readily available in Virago and Vintage editions). Like the Modern Library in the 1930s, today's paperback publishers contribute to shaping the literary canon by allowing a wide audience of students and teachers to read the work of a major American writer. 


\section{APPENDIX}

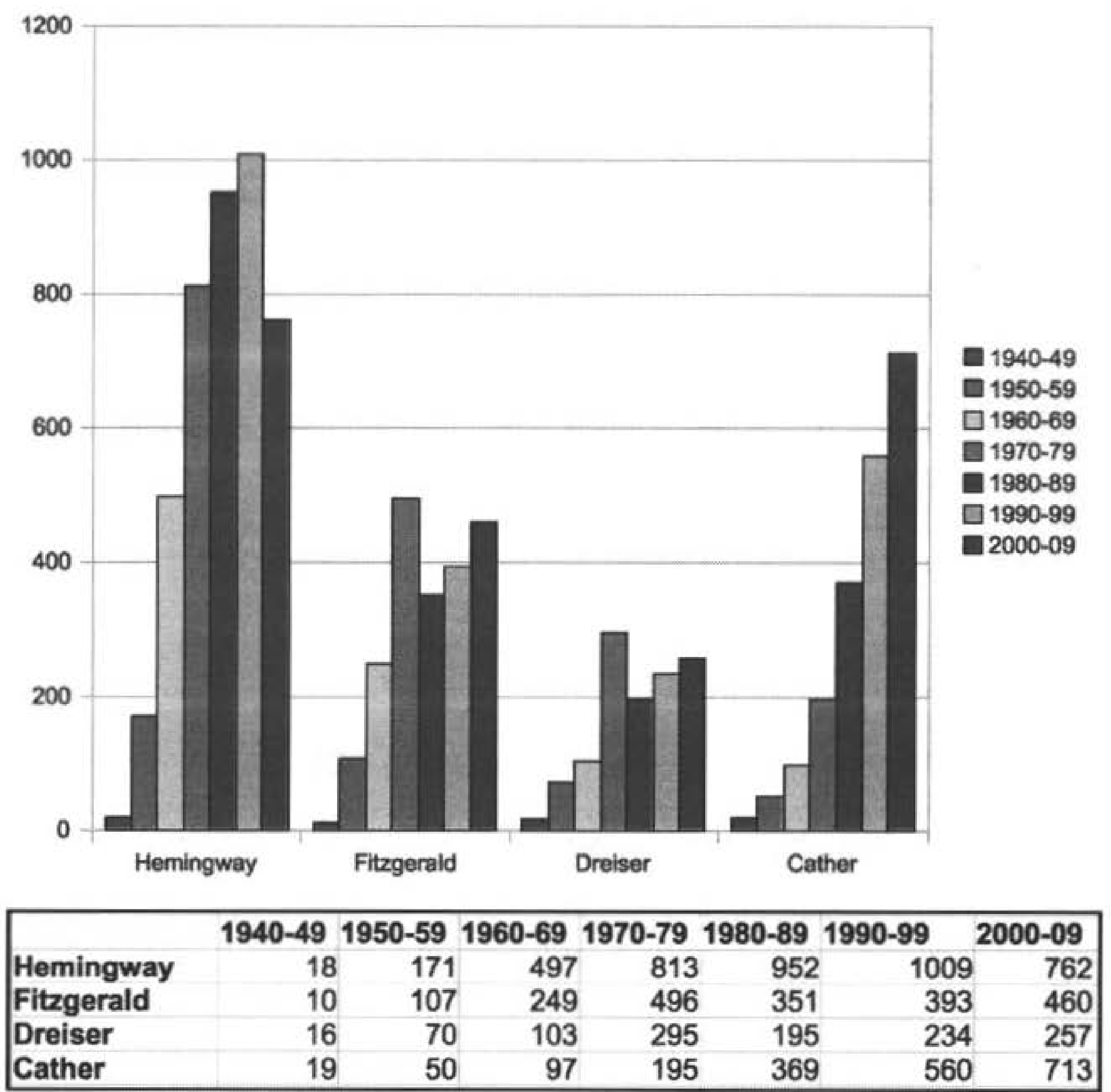

Fig. 5: MLA Bibliography Entries for Selected American Writers, 1940-2009

Note on methodology: I have compiled these figures using the MLA International Bibliography (accessed through EBSCO database). Results include all articles, books, reviews, and theses that contain "Cather, Willa" (or "Dreiser, Theodore," etc.) as a keyword. This methodology is inspired by David Damrosch's chapter "World Literature in a Postcanonical, Hypercanonical Age."

\section{ABBREVIATIONS}

Columbia: Random House records, Rare Book \& Manuscript Division, Columbia U Lib. Dobkin: Barbara Dobkin Foundation, New York, NY.

Harry Ransom: Alfred A. Knopf, Inc. archive, Harry Ransom Center, U of Texas at Austin Harvard: Houghton Mifflin archive, Houghton Lib., Harvard OHRO: Oral History Research Office Collection of the Columbia U Lib. UVA: Willa Cather papers, U of Virginia Small Special Collections Lib. 


\section{NOTES}

' Before the commercialization of the first paperbacks in the US in the late 1930s, the Modern Library and other "dollar series" offered the cheapest books on the market. But books remained much more expensive than other cultural products (magazines, newspapers) that sold for a few cents. In other words, the Modern Library targeted a large middle-class audience, but never reached the mass-market.

${ }^{2}$ For more on cheap series of reprints as canon makers, see Rose 116-145; Hammond; Friskney; and Spiers.

${ }^{3}$ For more on middlebrow institutions, see Rubin and Radway.

${ }^{4}$ See Kari Ronning's essay in this special issue. I am grateful to Andrew Jewell for pointing out this cheap edition.

5 Alfred A. Knopf, Inc. archive, Harry Ransom Center, U of Texas at Austin; Houghton Mifflin Co. records, Houghton Library, Harvard; Susan J. and James Rosowski Cather Collection, U of Nebraska-Lincoln Library; Philip L. and Helen Cather Southwick Collection, U of NebraskaLincoln Library; Willa Cather papers, U of Virginia Small Special Collections Library. 1 am grateful to Melissa Homestead and Andrew Jewell for their assistance. Archival research at Columbia University Library was made possible by a Reese fellowship from the Bibliographical Society of America.

6 The Modern Library book was not, in the strictest bibliographical sense, a new "edition" since it was printed from the same plates as the Knopf trade edition. However, in this essay, I follow the example of the bibliographer Joan Crane who uses the term "Modern Library edition" $(134,139)$.

${ }^{7}$ The International Copyright Act of 1891 protected foreign authors only if the American edition was composed and printed in the United States. In 1904, the American publisher G. P. Putnam's Sons had used sheets from the British edition for its own issue of Green Mansions, thus leaving the work unprotected in the United States.

${ }^{8}$ Knopf's series was launched in 1920 to exploit the firm's growing backlist.

9 After seeing Adler's design for April Twilights, Cather wrote to him: "We have set a new standard of relations between writer and printer. The pains you have taken with this volume and the absolutely satisfying result you have achieved have quite revived my interest in the text." Qtd. in Blumenthal 109. See also Matthew Lavin's essay in this special issue.

10 The Counterfeiters appeared in the Modern Library in 1931.

" Random House to Knopf Inc., 11 Oct. 1929. Even for Pearl Buck's bestseller The Good Earth, the Modern Library guaranteed to reprint 15,000 copies to begin with and, in early 1934, paid an advance royalty of $\$ 1,500$ corresponding to ten cents per copy. K. M. to Rimington, 1 Feb. 1934.

${ }^{12}$ Following Madigan's work on the Book-of-the-Month club, it would be interesting to investigate Cather's involvement with smaller book clubs such as the Catholic Book Club.

13 Cerf to Hugh Eayrs, 2 Sept. 1931. Eayrs, the president of the Macmillan Company of Canada, responded by doubling his initial order of Cather's novel. Eayrs to Cerf, 8 Sept. 1931.

${ }^{14}$ See, for examples, Publishers' Weekly 14 Jan. 1928: 139 and New York Times Book Review 18 March 1928: 26.

is Von Schmidt's drawings also appeared in the illustrated edition of Death Comes for the Archbishop (1929) and in December Night, the first separate edition of chapter 7 (1933).

${ }^{16}$ It might also be argued that there was a level of practices that distinguished all Cather titles as a group from other Borzoi books.

${ }^{17}$ Of course, "classic" is a problematic word, partly because of its use as a marketing category. In her study of the Oxford World's Classics series, Mary Hammond notes that "a book is a 'classic' almost wholly because a particular publisher says it is" (94).

18 "Publicity" folder, box 117 , Columbia.

19 Cather asked Knopf for an increase in royalty on Death Comes for the Archbishop, suggesting that his son would continue to make payments to her own niece (Knopf, "Miss Cather" 210).

${ }^{20}$ This claim is repeated in the 1999 scholarly edition of Archbishop: "the fourth and last Modern Library printing was in July 1933" (Mignon et al. 521).

${ }^{21}$ Box 71, Columbia. 
${ }^{22}$ After the Modern Library edition was discontinued, the illustrated edition became the standard text (Crane 139).

${ }^{23}$ The Modern Library edition of Archbishop sold approximately as many copies in five years as Virginia Woolf's Mrs. Dalloway did during the twenty years it stayed in the series (Kirkpatrick and Clarke 40).

${ }^{24}$ See Knopf to WC, 5 May 1932.

${ }^{25}$ There was a first printing of 3,000 copies of the Travellers' Library edition in September 1932 , and a second printing of 2,000 copies in January 1936 (Production Ledger [A to C], Archives of Jonathan Cape Ltd, U of Reading Special Collections).

${ }^{26}$ See, for example, Blanche Knopf to WC, 6 June 1933.

27 Greenslet to WC, 17 May 1932; WC to Greenslet, 31 May 1932.

${ }^{28}$ Contract for the first edition of Death Comes for the Archbishop, Willa Cather Trust.

29 This applies to the first edition, not to the 1929 illustrated edition, which had a first printing of 2,500 copies and sold for $\$ 5$. There was no other printing of the illustrated edition until 1936 , the year the Modern Library edition was discontinued (Crane 139).

${ }^{30}$ Although Hartley was enthusiastic about Archbishop, he deplored the lack of "plan and purpose" of Shadows on the Rock (103).

${ }^{31}$ WC to Sergeant, 16 Aug. 1946; WC to Greenslet, 28 Aug. 1946.

${ }^{32}$ Boxes 80 and 130 , Columbia.

33 The law changed in 1998 to extend copyright to ninety-five years from the publication date.

\section{WORKS CITED}

Atkinson, Brooks. "Critic at Large." New York Times 24 Nov. 1961: 28.

Blumenthal, Joseph. The Printed Book in America. Hanover, NH: UP of New England, 1989.

Bourdieu, Pierre. The Field of Cultural Production: Essays on Art and Literature. Trans. Randal Johnson. New York: Columbia UP, 1993.

Brickell, Herschel. "The Literary Landscape." North American Review 232.5 (1931): 471-80.

"Cather Book Added to Modern Library." Deseret News 10 Oct. 1931: 12.

Cather, Willa. Letter to Alexander Woollcott. [4 Dec. 1943?]. bMS Am 1449 (246), Harvard.

-. Letter to Atcheson L. Hench. 16 May 1940. UVA.

-. Letter to Blanche Knopf. 16 Dec. 1931. Ed. Stout \#1089. Harry Ransom.

-. Letter to Burges Johnson. [1928?]. Ed. Stout \#933. Beinecke Lib., Yale U.

-. Letter to Elizabeth Shepley Sergeant. 16 Aug. 1946. Ed. Stout \#1736. Pierpont Morgan Lib.

-. Letter to Fanny Butcher. 1 Sept. 1927. Ed. Stout \#892. Newberry Lib.

-. Letter to Ferris Greenslet. 3 Feb. 1929. Ed. Stout \#960. Harvard.

-. Letter to Greenslet. 2 May 1932. bMS Am 1925 (341), folder 18, Harvard.

-. Letter to Greenslet. 31 May 1932. bMS Am 1925 (341), folder 18, Harvard.

-. Letter to Greenslet. 17 July 1932. bMS Am 1925 (341), folder 18, Harvard.

-. Letter to Greenslet. 31 Oct. 1932. bMS Am 1925 (341), folder 18, Harvard.

-. Letter to Greenslet. 28 Aug. 1946. Ed. Stout \#1737. Harvard.

-. Letter to Manley Aaron. 26 Apr. 1929. Dobkin.

-. Letter to Mr. Meromichey. 5 Oct. 1931. Box 2, UVA.

-. Youth and the Bright Medusa. U of Virginia Lib., 1996. Web.

Cerf, Bennett. Letter to Alfred Knopf. 30 Jan. 1929. Box 110, Columbia.

-. Letter to Carl Smalley. 2 July 1931. Box 155, Columbia.

-. Letter to Dale Warren. 13 Sept. 1943. Box 124, Columbia.

-. Letter to Hugh Eayrs. 2 Sept. 1931. Box 126, Columbia.

-. Letter to Manley Aaron. 19 Nov. 1929. Box 94, Columbia.

-. Letter to Robert Linscott. 25 Aug. 1925. Box 124, Columbia.

-. Reminiscences. 4 Oct. 1967. OHRO.

-. Reminiscences. [1967]. OHRO.

Chinery, Mary. "Wartime Fictions: Willa Cather, the Armed Services Editions, and the Unspeakable Second World War." Cather Studies 6 (2006): 285-96.

Crane, Joan. Willa Cather: A Bibliography. Lincoln: U of Nebraska P, 1982. 
Damrosch, David. "World Literature in a Postcanonical, Hypercanonical Age." Comparative Literature in an Age of Globalization. Ed. Haun Saussy. Baltimore: Johns Hopkins UP, 2006. 43-53.

Dettmar, Kevin J. H. "Writers Who Price Themselves Out of the Canon." Chronicle of Higher Education 4 Aug. 2006: B6-8.

Eayrs, Hugh. Letter to Bennett Cerf. 8 Sept. 1931. Box 126, Columbia.

Feltes, N. N. Literary Capital and the Late Victorian Novel. Madison: U of Wisconsin P, 1993.

Five Stories, by Willa Cather. Advertisement. New York Times 19 Feb. 1956: BR10.

Friskney, Janet. New Canadian Library: The Ross-McClelland Years, 1952-1978. Toronto: U of Toronto P, 2007.

Greenslet, Ferris. Letter to Cather. 17 May 1932. bMS Am 1925 (341), folders 38-39, Harvard.

—. Letter to Cather. 2 June 1932. bMS Am 1925 (341), folders 38-39, Harvard.

-. Letter to Cather. 21 Oct. 1932. bMS Am 1925 (341), folders 38-39, Harvard.

Guillory, John. "Canon, Syllabus, List: A Note on the Pedagogic Imaginary." Transition 52 (1991): 36-54.

Hammond, Mary. "'People Read so Much Now and Reflect so Little': Oxford University Press and the Classics Series." Reading, Publishing and the Formation of Literary Taste in England, 1880-1914. Aldershot: Ashgate, 2006. 85-115.

Hartley, L. C. "The Graph Sags." Sewanee Review 40.1 (1932): 103-04.

Hicks, Granville. "Bright Incidents." Forum Sept. 1931: vi, viii. Rpt. in O'Connor 377-78.

—. "The Case Against Willa Cather." English Journal 22.9 (1933): 703-10.

Hillyer, Dorothy. Letter to "Trade Wind" [Cerf]. 8 Nov. 1943. Box 124, Columbia.

Homestead, Melissa. "Middlebrow Readers and Pioneer Heroines: Willa Cather's My Ãntonia, Bess Streeter Aldrich's A Lantern in Her Hand, and the Popular Fiction Market." Crisscrossing Borders in Literature of the American West. Eds. Reginald Dyck and Cheli Reutter. New York: Palgrave, 2009. 75-94.

K. M. Memo to Mr Rimington. 1 Feb. 1934. Box 105, folder 49, John Day Company archives, Manuscripts Division, Princeton U Lib.

Kaufman, Kenneth C. "Rev. of Shadows on the Rock." Southwest Review 16 (1931): xi, xiii. Rpt. in $\mathrm{O}^{\prime}$ Connor 353-54.

Kirkpatrick, B. J., and Stuart N. Clarke. A Bibliography of Virginia Woolf. 4th ed. Oxford: Clarendon, 1997.

Klopfer, Donald. Letter to Alfred A. Knopf. 10 June 1936. Box 71, Columbia.

Knopf Inc. Letter to Cather. 21 Nov. 1929. Dobkin.

-. Letter to Cather. 10 Dec. 1946. Box 1, folder 6, Philip L. and Helen Cather Southwick Collection, $\mathrm{U}$ of Nebraska-Lincoln Lib.

Knopf, Alfred A. Letter to Cather. 5 May 1932. Dobkin.

—. Letter to Donald Klopfer. 9 June 1936. Box 71, Columbia.

- " "Miss Cather." The Art of Willa Cather. Eds. Bernice Slote and Virginia Faulkner. Lincoln: U of Nebraska P, 1974. 205-24.

Knopf, Blanche. Letter to Cather. 6 June 1933. Box 689, folder 4, Harry Ransom.

Linscott, Robert. Letter to Bennett Cerf. 25 Aug. 1925. Box 124, Columbia.

Madigan, Mark J. "Willa Cather and the Book-of-the-Month Club." Cather Studies 7.1 (2007): 68-85.

Mencken, H. L. "Mainly Fiction." Smart Set March 1919: 140, 141. Rpt. in O'Connor 88-89.

Mignon, Charles W., et al, eds. Death Comes for the Archbishop, by Willa Cather. Lincoln: U of Nebraska P, 1999.

Miller, E. L. "College Entrance Requirements in English: A Committee Report. II." English Journal 20.9 (1931): 714-29.

Mitchell, F. K., and Newman White I. "Brief Mention." American Literature 1.1 (1929): 107-11.

“A Modern Interview." College Store May 1936: 15, 41-42.

The Modern Library of the World's Best Books. Advertisement. New York Times 15 Apr. 1917: BR5.

The Modern Library Series. Advertisement. Publishers' Weekly 12 Sept. 1931: 1018.

The Modern Library Series. Advertisement. Scholastic Magazine 28 Oct. 1933: 25.

Neavill, Gordon B. "The Modern Library Series.” Diss. U of Chicago, 1984. 
O'Brien, Sharon. "Becoming Noncanonical: The Case Against Willa Cather." American Quarterly 40.1 (1988): 110-26.

O'Connor, Margaret Anne, ed. Willa Cather: The Contemporary Reviews. Cambridge: Cambridge UP, 2001.

Radway, Janice. A Feeling for Books: The Book-of-the-Month Club, Literary Taste, and MiddleClass Desire. Chapel Hill: U of North Carolina P, 1997.

Random House. Memo to Knopf Inc. 11 Oct. 1929. Box 110, Columbia.

Root, Amy. "Designing the Borzoi: Alfred A. Knopf, Inc., Creates a Brand of Excellence, 191529." Papers of the Bibliographical Society of America 103.4 (2009): 497-513.

Rose, Jonathan. The Intellectual Life of the British Working Classes. New Haven: Yale UP, 2001.

Rubin, Joan Shelley. The Making of Middlebrow Culture. Chapel Hill: U of North Carolina P, 1992.

"Sales Notes." Publishers' Weekly I1 July 1931: 166.

Satterfield, Jay. The World's Best Books: Taste, Culture, and the Modern Library. Amherst: U of Massachusetts P, 2002.

Shadows on the Rock. Advertisement. Publishers'Weekly 25 July 1931: 364.

Spiers, John, ed. The Culture of the Publisher's Series. 2 Vols. Basingstoke: Palgrave, 2011.

Stout, Janis P. A Calendar of the Letters of Willa Cather. Lincoln: U of Nebraska P, 2002.

Travis, Trysh. "Print and the Creation of Middlebrow Culture." Perspectives on American Book History: Artifacts and Commentary. Eds. Scott E. Casper, Joanne D. Chaison, and Jeffrey D. Groves. Amherst: U of Massachusetts P, 2002. 339-66.

Turner, Catherine. Marketing Modernism between the Two World Wars. Amherst: U of Massachusetts P, 2003.

Vanderbilt, Kermit. American Literature and the Academy: The Roots, Growth, and Maturity of a Profession. Philadelphia: U of Pennsylvania P, 1986.

West, James L. W. III. "Fitzgerald's Posthumous Literary Career." Journal of Scholarly Publishing 28.2 (1997): 92-101. 